of thinking too well of it, no subjective beliefs about the effects on skill are likely to have any validity.

Finally, it may be worth briefly considering the long-term results of ingesting small or moderate amounts of alcohol. The disastrous effects associated with heavy drinking-addiction, cirrhosis of the liver, delirium tremens, for instances-are well known, and it is apt to be assumed that as large doses are very harmful small doses are mildly so. As in the matter of driving, completely satisfactory evidence on this point depends on comparison of the health and longevity of abstainers, moderate drinkers and heavy drinkers, not differing from one another in any other relevant respects. Evidence of this sort can be obtained from insurance statistics, but much of it is unsatisfactory because the different groups are not comparable in some important respects. The best data still appear to be those of Pearl (1924), who found that the greatest expectation of life occurred in occasional and moderate drinkers, that abstainers on the whole lived slightly less and that heavy drinkers lived substantially less long. As the various groups are of course self-selected, this correlation does not prove that small doses of alcohol prolong life: the characteristics that provoke a man to abstain may be associated with other characteristics which predispose to an early death. But the available facts suggest that a man must drink rather a lot before alcohol is seriously harmful to him, and that it is not impossible that the consumption of a little alcohol daily may even be a beneficial practice rather than the reverse.

\title{
REFERENCES
}

Bahnsen, P. \& Vedel-Petersen, K. (1934). F. industr. Hyg. I6, 304.

Bjerver, K. \& Goldberg, L. (1950). Quart. F. Stud. Alc. II, I.

Edkins, N. \& Murray, M. M. (1931). 7. Physiol. 71, 403.

Gantt, W. H. (1940). Amer. F. Physiol. 129, 360.

Goldberg, L. (1943). Acta physiol. scand. 5, suppl. I6, p. I.

Holcomb, R. L. (1938). F. Amer. med. Ass. III, 1076.

Hollingworth, H. L. (1923a). F. abnorm. (soc.) Psychol. 18, 204.

Hollingworth, H. L. (1923b). F. abnorm. (soc.) Psychol. 18, 3 I I.

Jacobsen, E. (1952). Pharmacol. Rev. 4, 107.

Jellinek, E. M. \& McFarland, R. A. (I940), Quart. $\mathcal{~ . ~ S t u d . ~ A l c . ~ 1 , ~} 272$.

Jetter, W. W. (1938). Amer. F. med. Sci. 196, 475.

Liljestrand, G. (1940). Quoted by Goldberg, 1943.

McDougall, W. \& Smith, M. (1920). Spec. Rep. Ser. med. Res. Coun., Lond., no. 56.

Mellanby, E. (I9I9). Spec. Rep. Ser. med. Res. Coun., Lond., no. 3 I.

Newman, H., Fletcher, E. \& Abramson, M. (1942). Quart. F. Stud. Alc. 3, 15.

Pearl, R. (1924). Brit. med.7. i, 948.

Rivers, W. H. R. \& Webber, H. N. (r9o8). Brit. F. Psychol. 2, 26 r.

Shakespeare, W. (1623). Macbeth, Act 2, Scene 3 .

van Dyke, H. B. \& Ames, R. G. (195I). Acta endocr., Copenhagen, 7, I Io.

Vernon, H. M. (г19). Spec. Rep. Ser. med. Res. Coun., Lond., no. 34.

\section{Vitamin Deficiencies in Alcoholism}

\section{By H. M. Sinclair, Laboratory of Human Nutrition, University of Oxford}

It is a matter of common experience that the drinking habits of different people vary. This profound observation explains why, for instance, the Boston City Hospital can fill a ward with cases of alcoholic neuritis drinking cheap wood spirit whereas 
the disease is very rare in our beer-drinking country-so rare that when I was studying it before the war I found it almost impossible to find cases except for occasional ones amongst retired colonels drinking whiskey in Belfast, and even this band of gallant gentlemen is becoming obsolete. Two separate questions must be considered: do vitamin deficiencies cause alcoholism, and, does alcoholism cause vitamin deficiencies?

\section{Vitamin deficiencies as a cause of alcoholism}

Williams (1946, I947, 1950) has introduced the concept of 'genetotrophic disease' in which the basic lesion is a partial block of genetic origin in a metabolic path which 'calls for an augmented supply of a particular nutrient (or nutrients), for which there develops, as a result, a nutritional deficiency' (Williams, Beerstecher \& Berry, 1950). This concept arose from the study of the appetite of rats and mice for alcohol. When given a choice between ro $\%$ alcohol and water, some animals appeared to be constitutionally teetotallers while others exhibited a relatively strong appetite even from the start. On abundantly adequate diets no animals drank more than a small amount of alcohol, but inadequate diets increased the amount consumed; this amount could be promptly decreased by supplementation of the inadequate diets.

Similar studies have been conducted by Mardones (195I), who believes that lack of a 'Factor $\mathrm{N}_{1}$ ' (found in yeast, liver, meat and wheat germ) and of other nutrients (particularly thiamine) causes increased consumption of alcohol. This work, as pointed out by Lester \& Greenberg (1952), was not properly conducted. They allowed rats saccharine or extra sucrose or fat, and found these supplements decreased alcohol consumption; the desire for supplementary fluid was not necessarily caloric since saccharine decreased the alcohol consumed and since more calories were derived from the sucrose solution than from the alcohol it replaced. Though the rats apparently liked alcohol, none became intoxicated.

The effect upon alcohol consumption of dietary reduction in calories or thiamine has been further investigated by Westerfeld \& Lawrow (1953). Rats allowed only half the food eaten by controls which were fed freely consumed more alcohol. A few thiamine-deficient rats consumed more alcohol when the food eaten fell to half the initial level and they lived longer than those that did not increase their alcohol consumption; almost all pair-fed controls consumed markedly more alcohol and apparently in consequence lived longer, but only one third of the calories that were withheld were compensated for by the ingestion of alcohol. It appears that reduction in calories, but usually not thiamine deficiency, causes increased drinking of alcohol in the rat.

Arguing from his studies on rats to man, Williams (1950) has suggested that the craving for alcohol displayed by the alcoholic may arise from a metabolic disorder, for instance in the metabolism of alcohol, similar to the craving for salt shown in Addison's disease. To overcome such a metabolic block, vitamin supplements were given to rats (Brady \& Westerfeld, 1947) or to six persons (Smith, 
Dardin \& Brown, 1951), but the latter study was brief and uncontrolled. A controlled investigation over 2 years has been made in Harvard (Trulson, Fleming \& Stare, 1954) into the effects of multiple vitamin therapy upon alcoholism in 207 patients. In some instances such therapy appeared to have a beneficial effect, but as a result of their large experience the authors are not optimistic about widespread benefit to be derived from vitamin therapy in the treatment of alcoholism in the present state of knowledge. However, from this and the earlier researches there are results sufficiently favourable to encourage further investigations.

\section{Vitamin deficiencies caused by alcoholism}

We are not here primarily concerned with acute alcoholism: a young man who accidentally received about $\mathrm{I} \mathrm{ml}$. absolute alcohol into his internal carotid artery began within a few seconds to be confused, to sing, to shout and to fight (PurvesStewart, 1928), but when these signs vanished after some minutes it might be supposed his vitamins were unimpaired. Yet there is evidence that alcohol itself may produce direct effects upon vitamin metabolism. This young man may have mobilized vitamin A from his liver stores, an effect of alcohol found in man and dogs by Clausen, Baum, McCoord, Rydeen \& Breese (1942), in man by Brenner \& Roberts (I943) and by Hoch \& Hoch (1946), and in dogs by Pett (1940). This effect of alcohol, however, was not found by Yudkin (1941) or by Hume \& Krebs (1949), and the latter workers failed to confirm Yudkin's observation of an improved dark adaptation after alcohol; in observations we made early in the war upon students we obtained in general a deterioration in dark adaptation after varying doses of alcohol, thereby confirming Mandelbaum (194r) and obtaining the expected result in view of the acute effect of alcohol on the higher centres (Medical Research Council: Alcohol Committee, 1938). Since alcohol dehydrogenase is concerned with the interconversion of vitamin $\mathrm{A}$ and retinene, alcohol might be expected to affect rod vision.

The acute effects are, then, relatively unimportant, and the effects of chronic alcoholism are varied. We cannot easily explain in physiological terms the wellknown characteristics of the habitual toper with his red nose, watery eye, tremor and psychical defects. About Io ml. alcohol can be oxidized hourly (Mellanby, 1919), and since this quantity is equivalent to $5^{6} \mathrm{Cal}$. a man could obtain about $\mathrm{r} 300 \mathrm{Cal}$. daily from alcohol. Beer may appear nowadays to be a highly expensive solution of a trace of malt with an odour of hops, but nutritionally a pint will provide the following approximate percentages of the nutritional requirements of a moderately active man: calories 7 , calcium 8 , phosphorus $\mathrm{I} 2$, thiamine 2 , nicotinic acid 66 , riboflavin 13 . The moderate beer drinker therefore obtains some vitamins of the B complex; since stimulation of appetite usually ensues, the Falstaffian appearance is produced with obesity but no other obvious nutritional disorder. But the continued consumption of spirits or wines leads to nutritional deficiencies for various reasons. First, alcohol causes in rats a reduction in food consumption which is not compensated by the alcohol calories consumed, and is not caused by chronic gastritis since it can 
be demonstrated as soon as alcohol feeding is begun (Klatskin, Krehl \& Conn, 1954). Secondly, chronic alcoholism frequently causes chronic gastritis with accompanying anorexia. Thirdly, apathy, indifference and later psychoses lead to an unbalanced dietary. Fourthly, this dietary imbalance is accentuated by economic difficulties. There is not necessarily a deficit of calories, but vitamin deficiencies are likely to arise from the combination of capricious appetite with consumption of a liquid high in alcohol and deficient in nutrients. The effects may most conveniently be discussed under the systems of the body that show the main defects.

\section{Liver}

Evidence is available from studies on man and lower animals that cirrhosis in chronic alcoholism is at least in part caused by nutritional deficiency. Best and his colleagues (Best, Hartroft, Lucas \& Ridout, 1949) prevented liver damage in rats given alcohol by administration of choline and wrongly concluded that alcohol increased the choline requirement by augmenting the calorie intake. This type of experimental work in lower animals has been extended and also applied to man particularly by Patek (Patek, Post, Ratnoff, Mankin \& Hillman, 1948), Klatskin (Klatskin \& Yesner, 1949; Klatskin, 1953; also vide infra), Post (Post, Benton, Breakstone \& Hoffman, I952) and others (Cayer \& Cornatzer, r952; Leevy, Zinke, White \& Gnassi, 1953). In general, the evidence indicates that alcoholic cirrhosis is caused by deficiency of lipotropic substances (such as choline or methionine or other methyl-group donors, vitamin $B_{12}$ and folic acid), that in its early stages the fatty infiltration is completely reversible but if not treated leads to fibrous changes, and that alcohol has no direct effect upon the liver cells in producing cirrhosis. This does not mean that alcoholic cirrhosis should be treated with a protein-rich diet and no attention paid to the alcohol: Sirnes (r953) found that rats with cirrhosis (though produced by carbon tetrachloride) had a voluntary intake of alcohol four times as great as in a control group with normal livers. The most recent work from Yale (Klatskin et al. 1954; Klatskin \& Krehl, I954) shows convincingly that rats on a diet marginal in lipotropic activity and containing alcohol develop fatty infiltration and fibrosis of the liver which appears to be due to alcohol increasing the requirement of choline but not in consequence of an augmented calorie intake. The mechanism whereby alcohol increases the requirement for methyl-group donors is therefore unknown.

A very common complication of cirrhosis is ascites. It can be controlled by severe restriction of dietary sodium (Gabuzda, Traeger \& Davidson, 1954), but this tells us little of the mechanism. Kowalski (Kowalski \& Abelmann, 1953; Kowalski, Abelmann \& McNeedy, 1954) has frequently found cardiac output increased; one suggested reason is a decreased peripheral resistance caused by a metabolic deficiency of thiamine as cocarboxylase.

Nervous system

There are three main conditions to be considered: peripheral neuropathy, encephalopathy and the psychoses. 
Psychoses. Delirium tremens and Korsakov's psychosis have become very rare in this country. The latter was noted as a complication of multiple neuritis usually alcoholic: 'psychosis polyneuritica seu cerebropathia psychica toxaemica' (Korsakov, I 890). Faulty memory, confabulation and disorientation in space and time are prominent features of Korsakov's psychosis, and the 'shaky madness' is accompanied by hallucinations. There is a large literature for and against the use of thiamine or nicotinamide in the treatment of these conditions. No aetiological relationship has been proved.

Wernicke's encephalopathy. Wernicke ( $188 \mathrm{I}$ ) described three fatal cases of 'acute superior haemorrhagic polio-encephalitis'; two were chronic alcoholics and the third followed attempted suicide by drinking sulphuric acid; there were focal haemorrhages in the grey matter around the third and fourth ventricles and the aqueduct of Sylvius. Though Prickett (r934) had noted haemorrhages in the pons, medulla and cerebellum of rats deficient in thiamine, Alexander (Alexander, Pijoan \& Myerson, 1938) first noted the similarity of the lesions in the human disease with those of pigeons acutely deficient in thiamine. Similar results were obtained in foxes (Green, Carlson \& Evans, I 94I) and cats (Ferraro \& Roizin, I94I). In patients with the disorder, whether of alcoholic origin or not, the blood pyruvate is raised (Wortis, Bueding, Stein \& Jolliffe, I942). The condition is very often fatal unless treated with thiamine; dramatic response to such therapy together with the almost universal presence of dietetic deficiency, the raised blood pyruvate and the production of similar lesions in lower animals, make it certain that the condition can arise from acute thiamine deficiency. There are occasional cases that cannot be ascribed to dietary deficiency of thiamine, and it is possible that these might be caused by some error in thiamine metabolism.

Alcoholic polyneuropathy. The early history from Lettsom (1786) onwards has often been reviewed. Minot and colleagues (Minot, Strauss \& Cobb, r933) made an important contribution from Harvard when they studied dietetically 130 cases; previously Minot's grandfather, also a Professor of Medicine in Harvard, had given a classical description of the disease under the title 'On a peculiar disease resulting from the use of ardent spirits' with running title 'On arthrodynia a potu' (Jackson, I822); he commented that in treatment 'animal food is most useful'.

Obviously the condition could be due to a direct effect of alcohol on the neurone or to alcoholism causing a secondary nutritional deficiency. Three vitamins are known to prevent peripheral neuropathy: thiamine, pyridoxin and pantothenic acid. The last two can be excluded because the syndrome produced by deficiency of these is quite different from that found in alcoholic polyneuropathy. It, however, is identical neurologically with chronic thiamine deficiency as manifested in dry beriberi. It is, for instance, worth noting that in the forms of peripheral neuropathy that are usually accompanied by raised blood pyruvate (dry beriberi, arsenical, alcoholic, gestational, and other neuropathies) marked tenderness of the calf muscles is found. I have discussed elsewhere the possibility that the neuropathy is caused by the raised concentration of pyruvate or some similar metabolite (Sinclair, r953); from the work of various authors (cf. Woolf, Griffiths \& Moncrieff, 1955) it appears 
that the mental deficiency of congenital phenylketonuria may be caused by the toxic effect upon neurones of the brain of phenylpyruvate or a closely related substance; and we have recently found that in strict vegetarians with low blood vitamin $\mathrm{B}_{12}$ there tends to be an increased concentration in blood of $p$-hydroxyphenylpyruvate which (or a closely related metabolite) might be toxic and so cause the subacute combined degeneration of the cord (Wokes, Badenoch \& Sinclair, 1955). Three closely related chemical substances might therefore be toxic to different types of neurones. It appears that alcohol spares thiamine (Lowry, Sebrell, Daft \& Ashburn, 1942; Westerfeld \& Doisy, 1945), that if alcohol is substituted for carbohydrate more derivatives of nicotinic acid and thiamine are excreted (Butler \& Sarett, 1948), and that administration of pyruvate increases the oxidation of alcohol in the dog (Westerfeld, Stotz \& Berg, I942); so the relationship between alcohol, pyruvate, and thiamine may be more complicated than one of dietetic deficiency of thiamine in the chronic alcoholic. Thus, I found 16 years ago that alcohol was a very powerful inhibitor of the enzymic phosphorylation of thiamine in the liver. Further, all of twenty-five cases of alcoholic polyneuropathy, about half of which also had Korsakov's psychosis, had a low blood total thiamine (Sinclair, 1939) and none of six cases gave normal values for blood cocarboxylase (Goodhart \& Sinclair, 1940).

We may note that if alcohol acts in part at least by decreasing the phosphorylation of thiamine, blood cocarboxylase will be decreased and pyruvate will accumulate; therapy with thiamine may be ineffective. But this triad, which occurs in alcoholic polyneuropathy (since therapy is often disappointing possibly because of irreversible damage), could arise in another way. Alcohol is oxidized in the body by alcohol dehydrogenase in presence of DPN to acetaldehyde (equation 3, p. I I3); the same enzyme catalyses the interconversion of vitamin $A$ and retinene, but it does not oxidize methanol. But methanol, like ethanol, is oxidized to acetaldehyde by hydrogen peroxide (formed for instance by xanthine oxidase) in presence of catalase, and this route may account for about a fifth of the oxidation of ethanol. The acetaldehyde formed by either route can combine with one of the sulphydryl groups of lipoic acid (equation 5) and so block the transfer of decarboxylated pyruvate from cocarboxylase $\overline{(\mathrm{TPP})}$ to lipoic acid $\mathrm{S}_{\mathrm{S}} \mathrm{L}$ (equation 2). In consequence there would be raised blood pyruvate, increased excretion of thiamine, lowered blood cocarboxylase and the same biochemical lesion in the neurone as in thiamine deficiency; treatment with lipoic acid should be effective:

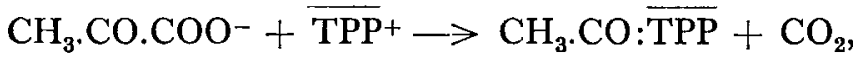

$$
\begin{aligned}
& \mathrm{CH}_{3} \cdot \mathrm{CO}: \overline{\mathrm{TPP}}+\underset{\mathrm{S} / \mathrm{\textrm {L }} \backslash \underset{-\mathrm{S} /}{\mathrm{L}} \rightarrow \mathrm{CH}_{3} \cdot \mathrm{CO}: \mathrm{S} \backslash}{\mathrm{TPP}}+
\end{aligned}
$$




$$
\begin{aligned}
& \mathrm{CH}_{3} \cdot \mathrm{CH}_{2} \mathrm{OH}+\overline{\mathrm{DPN}^{+}} \longrightarrow \mathrm{CH}_{3} \cdot \mathrm{CHO}+\overline{\mathrm{DPN}} \mathrm{H} \\
& \mathrm{CH}_{3} \cdot \mathrm{CO}: \overline{\mathrm{TPP}}+\mathrm{CH}_{3} \cdot \mathrm{CHO} \rightarrow \mathrm{CH}_{3} \cdot \mathrm{CO} \cdot \mathrm{CHOH} \cdot \mathrm{CH}_{3}+\overline{\mathrm{TPP}}+
\end{aligned}
$$

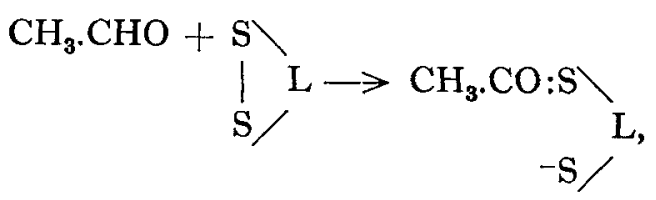

$$
\underset{-\mathrm{S} /}{\mathrm{CH}_{3} \cdot \mathrm{CO}: \mathrm{S} \backslash}+\overline{\mathrm{CoA} S H}+\overline{\mathrm{DPN}^{+}} \rightarrow \mathrm{CH}_{3} \cdot \mathrm{CO}: \overline{\mathrm{SCoA}}+\left.\right|_{\mathrm{S}} ^{\mathrm{L}} \mathrm{L}+\overline{\mathrm{DPN}} \mathrm{H} .
$$

Despite the fact that acetaldehyde can form acetoin (equation 4) and can apparently also be oxidized to acetate in presence of diphosphopyridine nucleotide $(\overline{\mathrm{DPN}})$ without participation of coenzyme $\mathrm{A}(\overline{\mathrm{CoA}})$ (Walkenstein \& Weinhouse, 1953), only limited amounts of alcohol can be oxidized in the body, and the limiting factor might well be lipoic acid. It would appear that thiamine is not needed for the oxidation of alcohol by alcohol dehydrogenase or of acetaldehyde by acetaldehyde dehydrogenase, but infusing acetaldehyde into dogs given oxythiamine lowers blood glucose while raising blood pyruvate and acetaldehyde as compared with infusions into normal dogs (Hulpieu, Clark \& Onyett, 1954); the rise in acetaldehyde might occur through inhibition of formation of acetoin (equation 4). There are therefore ways other than a conditioned deficiency of thiamine that could cause alcoholic neuropathy: inhibition of the phosphorylation of thiamine or inhibition of lipoicacid catalysis. One is tempted to believe that chronic toxicity of acetaldehyde in the chronic alcoholic (and perhaps of methylglyoxal in chronic thiamine deficiency) may cause neuropathy, and it is therefore perhaps not surprising that tetraethylthiuram disulphide (Antabuse), which inhibits the oxidation of acetaldehyde, can cause neuropathy.

\section{SUMMARY}

I. Reduction in calories, but not usually thiamine deficiency, appears to increase the amount of alcohol ingested by the rat. Although it is possible that dipsomania can arise in man from a metabolic disorder in the metabolism of alcohol which can be overcome by massive doses of one or more nutrients, no dramatic success of such therapy has yet been achieved.

2. Alcohol mobilizes vitamin A from liver stores, but does not improve the final rod threshold of the dark-adapted eye.

3. Alcohol appears to have a direct effect in decreasing food consumption. Chronic alcoholism enhances this direct effect in various ways and can lead to nutritional deficiency. 
4. Laennec's cirrhosis in chronic alcoholism is caused by dietary deficiency of lipotropic substances. The mechanism whereby alcohol increases the requirement of methyl-group donors is unknown.

5. Alcoholic psychoses have not been proved to be caused by nutritional deficiency, but acute deficiency of thiamine can cause Wernicke's encephalopathy.

6. Alcoholic polyneuropathy appears to be closely related to the function of thiamine but is not necessarily caused by its dietary deficiency. Decreased phosphorylation or blocking of the catalytic action of lipoic acid might play a part.

\section{REFERENCES}

Alexander, L., Pijoan, M. \& Myerson, A. (1938). Trans. Amer, neurol. Ass. 64, 135.

Best, C. H., Hartroft, W. S., Lucas, C. C. \& Ridout, J. H. (1949). Brit. med. J. ii, roor.

Brady, R. A. \& Westerfeld, W. W. (1947). Quart. F. Stud. Alc. 7, 499.

Brenner, S. \& Roberts, L. J. (I943). Arch. intern. Med. 71, 474.

Butler, R. E. \& Sarett, H. P. (1948). F. Nutr. 35, 539.

Cayer, W. D. \& Cornatzer, W. E. (1952). Gastroenterology, 20, 385.

Clausen, S. W., Baum, W. S., McCoord, A. B., Rydeen, J. O. \& Breese, B. B. (1942). I. Nutr. $24,1$. Ferraro, A. \& Roizin, L. (I94I). Trans. Amer. neurol. Ass. 67, I77.

Gabuzda, G. J., Traeger, H. S. \& Davidson, C. S. (1954). F. clin. Invest. 33, 780.

Goodhart, R. \& Sinclair, H. M. (1940). F. biol. Chem. r32, I I.

Green, R. G., Carlson, W. E. \& Evans, C. A. (1941). F. Nutr. 21, 243.

Hoch, H. \& Hoch, R. (1946). Brit. F. exp. Path. 27, 316.

Hulpieu, H. R., Clark, W. C. \& Onyett, H. P. (1954). Quart. F. Stud. Alc. 15, I89.

Hume, E. M. \& Krebs, H. A. (1949). Spec. Rep. Ser. med. Res. Coun., Lond., no. 264.

Jackson, J. (1822). New Engl. F. Med. Surg. II, 351 .

Klatskin, G. (1953). Yale f. Biol. Med. 26, 23.

Klatskin, G. \& Krehl, W. A. (1954). F. exp. Med. roo, 615.

Klatskin, G., Krehl, W. A. \& Conn, H. O. (1954). F. exp. Med. roo, 605.

Klatskin, G. \& Yesner, R. (1949). F. clin. Invest, 28, 723.

Korsakov, S. (1890). Allg. Z. Psychiat. 46, 475.

Kowalski, H. J. \& Abelmann, W. H. (1953). F. clin. Invest. 32, 1025.

Kowalski, H. J., Abelmann, W. H. \& McNeedy, W. F. (1954). F. clin. Invest. 33, 768.

Leevy, C. M., Zinke, M. R., White, T. J. \& Gnassi, A. M. (1953). Arch. intern. Med. 92, 527.

Lester, D. \& Greenberg, L. A. (1952). Quart. F. Stud. Alc. 13, 553.

Lettsom, J. C. (1786). Mem. med. Soc. Lond. I, 128 .

Lowry, J. V., Sebrell, W. H., Daft, F. S. \& Ashburn, L. L. (r942). F. Nutr. $24,73$.

Mandelbaum, J. (194Y). Arch. Ophthal., N.Y., 26, 203.

Mardones, R. J. (195I). Quart. F. Stud. Alc. 12, 563.

Medical Research Council: Alcohol Committee (1938). Alcohol: its Action on the Human Organism London: H.M. Stationery Office.

Mellanby, E. (1919). Spec. Rep. Ser. med. Res. Coun., Lond., no. 31.

Minot, G. R., Strauss, M. B. \& Cobb, S. (1933). New Engl. F. Med. 208, 1244.

Patek, A. J., Post, J., Ratnoff, O. D., Mankin, H. \& Hillman, R. W. (1948). F. Amer. med. Ass. 138, 543.

Pett, L. B (1940). Science, 92, 63.

Post, J., Bentón, J. G., Breakstone, R. \& Hoffman, J. (1952). Gastroenterology, 20, 403.

Prickett, C. O. (1934). Amer. F. Physiol. 107, 459

Purves-Stewart, J. (1928). Practitioner, 120, 175.

Sinclair, H. M. (1939). Int. neurol. Congr. III. Copenhagen, p. $88_{5}$.

Sinclair, H. M. (1953). The Work of Sir Robert McCarrison. London: Faber and Faber.

Sirnes, T. B. (1953). Quart. F. Stud. Alc. 14, 3.

Smith, J. A., Dardin, P. A. \& Brown, W. T. (I95I). Quart. F. Stud. Alc. 12, 38 r.

Trulson, M. F., Fleming, R. \& Stare, F. J. (1954). F. Amer. med. Ass. 155, 14.

Walkenstein, S. S. \& Weinhouse, S. (1953). F. biol. Chem. 200, 5 I 5.

Wernicke, K. (1881). Lehrbuch der Gehirnkrankheiten fur Frzte und Studierende, Vol. 2, p. 229. Berlin: T. Fischer.

Westerfeld, W. W. \& Doisy, E. A. Jr. (1945). F. Nutr. 30, 127.

Westerfeld, W. W. \& Lawrow, J. (1953). Quart. F. Stud. Alc. 14, 378.

Westerfeld, W. W., Stotz, E. \& Berg, R. L. (1942). F. biol. Chem. 144, 657. 
Williams, R. J. (1946). The Human Frontier. New York: Harcourt, Brace and Co.

Williams, R. J. (1947). Quart. F. Stud. Alc. 7, 567.

Williams, R. J. (1950). Nutr. Rev. 8, 257.

Williams, R. J., Beerstecher, E. Jr. \& Berry, L. J. (1950). Lancet, 258, 287.

Wokes, F., Badenoch, J. \& Sinclair, H. M. (1955). Voeding, 16, 590.

Woolf, L. I., Griffiths, R. \& Moncrieff, A. (1955). Brit. med. F. i, 57.

Wortis, H., Bueding, E., Stein, M. H. \& Jolliffe, N., (1942). Arch. Neurol. Psychiat. Chicago, 47, 2 г.

Yudkin, S. (1941). Lancet, 241, 787.

\title{
Some Traditional Alcoholic Beverages and their Importance in Indigenous African Communities
}

\author{
By B. S. Platt, Human Nutrition Research Unit, Medical Research Council \\ Laboratories, Holly Hill, London, N.W.3
}

Fermented honey drinks may have been the earliest alcoholic beverages known to man and the discovery of them has been attributed to the Hamites (Seyffert, I930). Another hypothesis of the origin of alcoholic liquors is that they were first encountered when wild fruits were stored in clay-lined holes in the ground (Renard, 1929). If beer was not in fact originally brewed by man in Africa, some alcoholic fermentations were developed on that continent. According to the mythology of the Egyptians, their first queen, Isis, discovered wheat and barley growing wild and king Osiris devised means of cultivating them. Osiris is reputed to have introduced the vine from his native country, probably Syria or Palestine, taught its cultivation and the making of wine and the brewing of beer, and, ultimately, he toured the rest of the inhabited earth, which included Ethiopia, teaching mankind how to sow wheat and barley, how to cultivate the vine, and how to enjoy their fruits. One interpretation of this Egyptian tradition is that the knowledge of the cultivation of wheat, barley and the vine, and of the making of beer and wine, was introduced into Egypt by people coming from Syria or Palestine at a very early period-long before the first dynasty, which began about 3400 B.C.; the knowledge of these arts of civilization later spread to India, Europe and Ethiopia. The mountainous part of East Africa, chiefly Abyssinia, has been postulated (Vavilov, 193I) as one of seven fundamental independent centres of the origin of cultivated plants: in this instance, of wheat, barley, sorghum and coffee. There is no archaeological support for this postulate. Evidence exists, however, that between 6000 and 5000 B.C. the Fayum folk, a late Stone Age people living in the Nile valley, cultivated barley of a kind similar to that still grown in Egypt. Although the earliest history of alcoholic fermentation is not known, it does seem likely that in Africa it is a process of considerable antiquity.

There are five main groups of African alcoholic beverages: fermented honey water; fermented fruits and juices; fermented sap from various species of palm and a bamboo*; drinks made from milk, and the beers. All of these have more or less

- The Oxytenanthera braunii Pilger (Greenway, 1945-6). 